\title{
Ultrastructural studies of oogenesis in the variable abalone Haliotis varia (Vetigastropoda: Haliotidae)
}

\author{
T. M. Najmudeen* \\ Department of Marine Biology, Microbiology and Biochemistry, School of Ocean Science and Technology, \\ Cochin University of Science and Technology, Cochin-16, India
}

\begin{abstract}
Ultrastructural features of the ovary as well as oogenesis were examined in the variable abalone Haliotis varia with the help of transmission electron microscopy. Based on the ultrastructure, the female germ cells were divided into 5 stages; oogonia, pre-vitellogenic, early vitellogenic, late vitellogenic and mature oocytes. Oogonia were supported by follicle cells that lined up the inner walls of the ovary. Vitellogenesis in $H$. varia commenced at about $50 \mu \mathrm{m}$ oocyte diameter, with a major contribution by the autosynthetic pathway. Lipid droplets and protein yolk granules, measuring $2.3 \pm 0.2$ and $2.5 \pm 0.3 \mu \mathrm{m}$, respectively, were observed in late vitellogenic and mature oocytes. Vitellogenic oocytes were encircled by a vitelline envelope consisting of a single layer of about $2.3 \mu \mathrm{m}$ thickness. Numerous microvilli were embedded in the vitelline envelope. Cytoplasmic inclusions such as cortical granules, lipid droplets, mitochondria and yolk granules constituted the fundamental components of the mature oocyte. The cortical granules were arranged beneath the oolemma at the cortex of the oocyte. Oocyte degeneration in $H$. varia was observed in all stages of oocyte development, except in oogonial cells and pre-vitellogenic oocytes.
\end{abstract}

KEY WORDS: Female germ cells · Haliotis varia · Ovarian maturation · Variable abalone · Ultrastructural studies · Vitellogenesis

Resale or republication not permitted without written consent of the publisher

\section{INTRODUCTION}

Vitellogenesis in marine molluscs is a complex process involving both autosynthetic and heterosynthetic pathways that contribute to the accumulation of more than one type of storage product (Eckelbarger \& Young 1997, Dreon et al. 2002, Pal \& Hodgson 2002, Matsumoto et al. 2003). Various kinds of yolk components in this group may be formed in many different ways, directly or indirectly, from the Golgi bodies, mitochondria, or nucleolar material, or independently in the cytoplasm (Eckelbarger \& Davis 1996, Osada et al. 2003). In some groups, there is strong evidence for the involvement of extra ovarian components in vitellogenesis (Amor et al. 2004). Many authors have discussed the role of ovarian ultrastructure and the mechanisms of vitellogenesis on the evolutionary forces that shaped the life-history patterns of marine gastropods (Eckelbarger 1994, Hodgson \& Eckelbarger 2000, Hodgson et al. 2002, Pal \& Hodgson 2002, Pal 2007).
Whilst the gametogenic cycle and gonad histology of various abalone species have been extensively studied (reviewed by Hahn 1989), there is less literature on the ultrastructural changes taking place in their germ cells. Most of the investigations along this line have focused on the fine-structure analysis of spermatozoa and cytochemistry of acrosomal vesicles (e.g. Healy et al. 1998, Galindo et al. 2003). Several authors have classified the female germ cells of abalone, in both temperate and tropical habitats (Young \& DeMartini 1970, Takashima et al. 1978, Martin et al. 1983). Nevertheless, there is no consensus in assigning the number of stages to ovarian cells, and most of these studies have been based on the histological examination and subsequent structural features obtained. Classification of ovarian cells based on ultramicroscopic observations is comparatively rare, and the available literature only describes the oogonial cells in detail (Martin et al. 1983, Sobhon et al. 1999, Apisawetakan et al. 2001). 
Haliotis varia, one of the least exploited species of tropical abalone, is distributed in India along the Gulf of Mannar on the east coast, and at Andaman and Nicobar Islands. It is a small tropical species, attaining a maximum shell length of $8 \mathrm{~cm}$ (Wilson 1993). There is no report of commercial exploitation of this species in India, which is attributed to its small size and limited distribution. However, recent increase in the demand for small cocktail size abalone in many Asian markets (Guo et al. 1999) has created interest in developing methods for the artificial propagation of this species. Some aspects of its reproductive biology and larval rearing have been investigated recently (Najmudeen \& Victor 2004a,b, Najmudeen 2007a,b). Studies on the annual reproductive cycle of this species in India confirm that the peak breeding season extends from December to March, with asynchronous spawning by individuals (Najmudeen 2007b). All gonad maturity stages were found throughout the year, suggesting that gametogenesis is a continuous process. Bussarawit et al. (1990) also proposed greater gametogenic activity in this species, based on their observations of rapid post-spawning recovery at Phuket, Thailand. Except for these reports, there is no published information on the reproductive biology of this species. In India, gonad maturation was associated with variation in water temperature and salinity; the seasonal low values coincided with the breeding season of $H$. varia (Najmudeen \& Victor 2004b). Since the determination of gonad maturity stages using histological examination is inadequate, in most cases, to identify the gamete stages involved and to delineate the exact process of vitellogenesis, it is important to carry out an ultrastructural study of the gonad. In this perspective, the present paper examines the ultrastructural changes of the female germ cells during maturation in the variable abalone $H$. varia based on transmission electron microscopy (TEM), to describe the process of vitellogenesis and to supplement additional information for the classification of female germ cells.

\section{MATERIALS AND METHODS}

Adult specimens of female Haliotis varia were collected from the intertidal rocks at Tuticorin Harbour basin of the Gulf of Mannar, southeast coast of India $\left(08^{\circ} 45^{\prime} \mathrm{N}, 78^{\circ} 12^{\prime} \mathrm{E}\right)$ from a depth of $2 \mathrm{~m}$ in January and February 2000. Immediately after collection, pieces of ovary from 20 animals (size range from 35 to $56 \mathrm{~mm}$ shell length) were separated from the digestive gland tissue and placed in fresh cold $\left(4^{\circ} \mathrm{C}\right)$ primary fixative of $3 \%$ gluteraldehyde buffered with $0.2 \mathrm{M}$ cacodylate containing $2 \%$ tannic acid and $6 \%$ glucose at $\mathrm{pH} 7.2$, for $3 \mathrm{~h}$. For TEM, fragments of selected material were washed 3 times in cacodylate buffer for about $15 \mathrm{~min}$ each time and post-fixed in $1 \%$ buffered osmium tetroxide for about $1 \mathrm{~h}$ at $4^{\circ} \mathrm{C}$. Properly fixed tissues were again washed in cacodylate buffer and then dehydrated in a graded acetone series. The tissues were infiltrated and embedded in a low-viscosity, resin-embedding medium (Spurr 1969) and kept at $60^{\circ} \mathrm{C}$ for $36 \mathrm{~h}$. Ultra-thin sections (50 to $60 \mathrm{~nm}$ ) were cut from the polymerized blocks using a glass knife on an ultramicrotome (LKB BROMA). The sections collected on uncoated copper grids were stained in $1 \%$ uranyl acetate in methanol and lead citrate. After drying, the grids were examined under a Hitachi 600 electron microscope at $50 \mathrm{kV}$ and relevant areas were photographed using Graphic Kodak lithe film.

\section{RESULTS}

Major changes during ovary maturation in Haliotis varia were the formation of a germinal vesicle and of yolk granules and, finally, oocyte maturation. Based on the changes in size and cytoplasmic contents of oocytes, 5 stages of oocytes were distinguished in $H$. varia, which are dealt with in detail in the following sections.

\section{Oogonia}

In the ovary, the germinal epithelium lined the inner ovarian wall. Cells in the germinal epithelium were initially cuboidal and as they enlarged, became oval or round oogonia. The oogonial cells in the ovary were supported by follicle cells, which lined up the perpendicularly running trabecular network (Fig. 1A). Oogonia had a diameter of $10 \pm 2 \mu \mathrm{m}( \pm \mathrm{SD}, \mathrm{n}=30)$ and were dominated by a large ovoid nucleus of $9 \pm 2.5 \mu \mathrm{m}( \pm \mathrm{SD}$, $\mathrm{n}=30$ ) diameter (Fig. 1B). The cytoplasm of oogonia contained numerous free ribosomes, mitochondria and some clusters of electron dense granules. Attached to the base of each oogonial cell were a few small follicle cells (Fig. 1C). The nucleus of oogonial cells contained lesscondensed chromatin materials scattered in the nucleoplasm. Nucleoli were not conspicuous at any stage of oogonia, and the oolemma appeared smooth and without any particular morphological specialization at this stage.

\section{Pre-vitellogenic oocytes}

The pre-vitellogenic oocytes of Haliotis varia were more elongated than the oogonia and measured $16 \pm$ $2 \mu \mathrm{m}( \pm \mathrm{SD}, \mathrm{n}=30)$ in diameter along their long axis (Fig. 1D). Nuclear volume increased, which measured $12 \pm 2 \mu \mathrm{m}( \pm \mathrm{SD}, \mathrm{n}=30)$ in diameter. As the pre-vitel- 

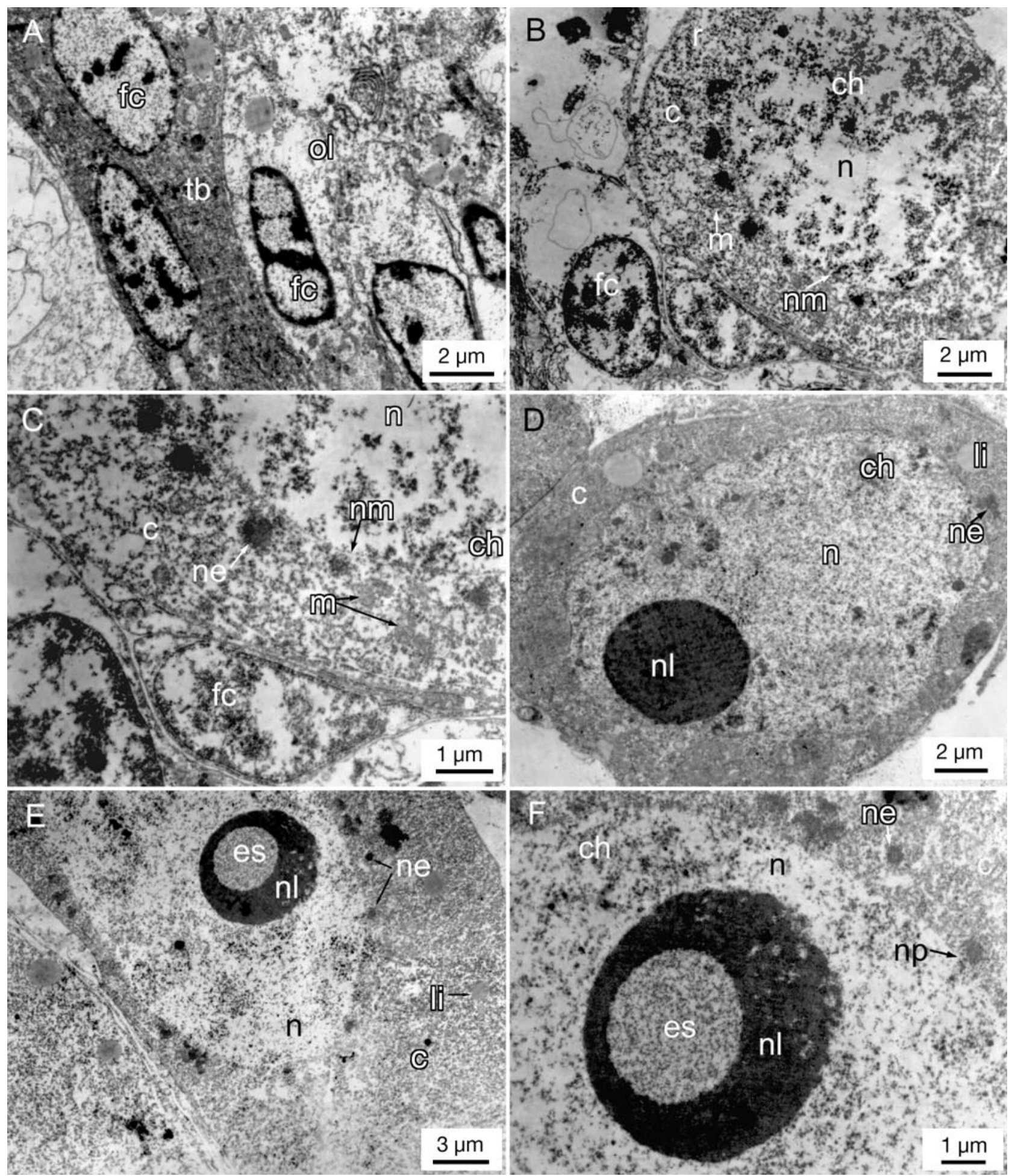

Fig. 1. Haliotis varia. TEM of developing ovary. (A) Ultrastructure of ovarian lumen (ol) showing the arrangement of follicle cells (fc) along the trabecular network (tb). (B) Fine structure of the oogonium with a well-defined nucleus (n) containing chromatin bodies (ch) and a nuclear membrane (nm); cytoplasm (c) contains numerous ribosomes (r) and mitochondria (m). (C) Enlarged view of oogonium showing granular nuclear emissions (ne), chromatin bodies and nuclear membrane. (D) Early vitellogenic oocyte with an enlarged clear nucleus and darkly stained nucleolus (nl), and lipid droplets (li) in the cytoplasm. (E) Early vitellogenic oocyte with increased cytoplasmic area and electron lucent space (es) in the nucleolus. (F) Enlarged view of an early vitellogenic oocyte showing the nuclear pores (np) and nuclear emissions (ne) 
logenic oocytes became larger, they moved away from the germinal epithelium and advanced towards the digestive gland, but remained attached by stalks. The cytoplasm became strongly basophilic, indicating considerable protein synthesis. As the enlargement of the oocyte progressed, the nuclear:cytoplasmic ratio of the oocyte decreased. The nucleoplasm contained lessdense chromatin materials. A prominent electron dense nucleolus was discernible in the nucleus of the oocyte at this stage. Numerous gaps or nuclear pores were evident in the nuclear wall, around which electron dense granular materials were clumped together (Fig. 1D). The cytoplasm of developing oocytes contained many ribosomes, mitochondria, Golgi bodies, as well as rough endoplasmic reticulum (ER) indicating active synthesis of protein.

\section{Early vitellogenic oocytes}

At about $50 \mu \mathrm{m}$ diameter, small, lightly stained spherical bodies appeared in the cytoplasm of the developing oocytes (Fig. 1E). This stage indicated the onset of yolk synthesis, i.e. vitellogenesis. Less electron dense, round lipid droplets appeared in the cytoplasm of early vitellogenic oocytes. Several cell organelles were present in the cytoplasm of the oocyte, which might be associated with the formation of yolk components. No pinocytes were seen in the early vitellogenic oocytes. The nucleus of early vitellogenic oocytes encompassed a clear round space (Fig. 1F). Large numbers of ribosome-studded, as well as smooth, membrane-bounded vesicles were also present in the cytoplasm of early vitellogenic oocytes (Fig. 2A).

\section{Late vitellogenic oocytes}

Cytoplasm of late vitellogenic oocytes was uniformly filled with various quantities of darkly stained protein yolk granules and lipid droplets (Fig. 2B). Small granular materials were also seen in the cytoplasm. The nucleus occupied a very large volume of the cytoplasm and migrated to the free end of the oocyte. The nucleolus was a dark, round, electron-dense body in the nucleoplasm. The late vitellogenic oocytes of Haliotis varia measured 80 to $120 \mu \mathrm{m}(\mathrm{n}=60)$ in diameter and were attached to the trabeculae in the ovarian lumen near the digestive gland. Large numbers of late vitellogenic oocytes were found in the late maturing stage ovaries of $H$. varia.

Concentric layers of rough ER were present surrounding the lipid droplets (Fig. 2C), indicating their role in lipid yolk synthesis. Numerous mitochondria and free ribosomes were also present in the cytoplasm.
Concentric and closed layers of smooth ER encompassing several granules and vacuoles were discernible in the vicinity of the nucleus. These were identified as membrane specializations and might be associated with the synthesis of yolk materials (Fig. 2E). As vitellogenesis progressed, these membrane specializations developed considerably, often encompassing several vesicles and yolk materials. Lipid droplets in the cytoplasm measured about $2.3 \pm 0.2 \mu \mathrm{m}( \pm \mathrm{SD}, \mathrm{n}=30)$ in diameter, and protein yolk vesicles measured about $2.5 \pm 0.2 \mu \mathrm{m}( \pm \mathrm{SD}, \mathrm{n}=30)$ in diameter (Fig. 2D). Other lamellar structures observed during vitellogenesis were annulate lamellae, which also originated in close proximity to the nucleus (Fig. 2F).

\section{Mature oocytes}

Mature oocytes of Haliotis varia measured $170 \pm$ $30 \mu \mathrm{m}( \pm \mathrm{SD}, \mathrm{n}=30)$ in diameter. A vitelline envelope appeared around the oolemma of mature oocytes, which measured $2.3 \pm 0.2 \mu \mathrm{m}( \pm \mathrm{SD}, \mathrm{n}=30)$ in thickness (Fig. 3A,B). Numerous microvilli were embedded in the vitelline envelope, arranged about $0.2 \mu \mathrm{m}$ apart. The free ends of the microvilli protruded out to the vitelline envelope. The nucleus was very large and less electron dense with a dark nucleolus. The cytoplasm contained numerous lipid droplets and protein yolk granules. Cortical granules, the membrane-bound vesicles, were seen in mature oocytes (Fig. 3B). They were round with a diameter of about $0.3 \mu \mathrm{m}$ and occupied a layer beneath the cytoplasmic membrane of the mature oocyte. Other types of cell organelles were not observed in the cytoplasm at this stage. At the final stage of oocyte maturation, the oocytes became detached from the trabeculae and tightly packed in the ovarian lumen.

\section{Degenerating oocytes}

Necrosis of vitellogenic oocytes was observed in vitellogenic and mature oocyte stages. The first visible sign of necrosis occurred in the nucleus. The chromatin became less granular; the nuclear membrane became convoluted and broke down. Numerous vacuoles appeared in the ooplasm, and the perivitelline space between the oolemma and vitelline envelope increased (Fig. 3C). The microvilli were separated from the oocyte surface, and finally the vitelline envelope disintegrated (Fig. 3D). The yolk vesicles were encircled by autophagic vacuoles. Genital blood vessels were also present near the degenerating oocytes (Fig. 3E). Early vitellogenic oocytes were also subject to degeneration. 

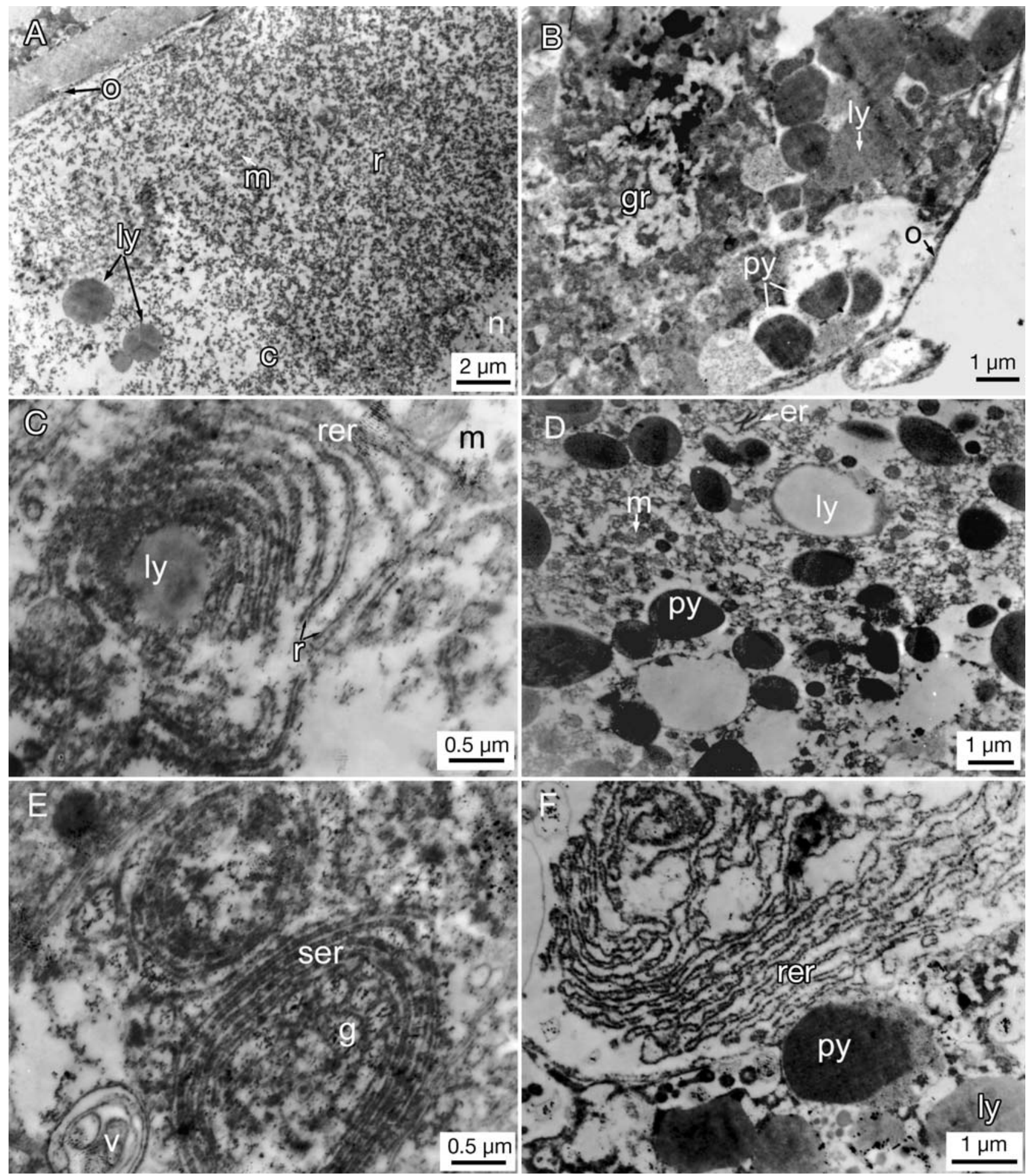

Fig. 2. Haliotis varia. TEM of developing and mature ovaries. (A) Cytoplasm of early viteloogenic oocyte that has initiated the synthesis of lipid yolk bodies (ly) and has numerous mitochondria (m), ribosomes (r) and a well-defined oolemma (o). c: cytoplasm; n: nucleus. (B) Late vitellogenic oocyte with both lipid yolk and protein yolk (py), and granular materials (gr). (C) Membrane specializations in the late vitellogenic oocyte encompassing lipid yolk components made up of rough endoplasmic reticulum (rer) containing ribosomes. (D) Cytoplasm of mature oocyte with its fundamental components: lipid yolk, protein yolk, mitochondria and endoplasmic reticulum (er). (E) Membrane specializations in the late vitellogenic oocyte that are formed by smooth endoplasmic reticulum (ser) and granular materials (g); some vacuoles (v) can also be seen. (F) Annulate lamellae in the cytoplasm of a late vitellogenic oocyte made up of rough endoplasmic reticulum and in close proximity to both lipid yolk and 

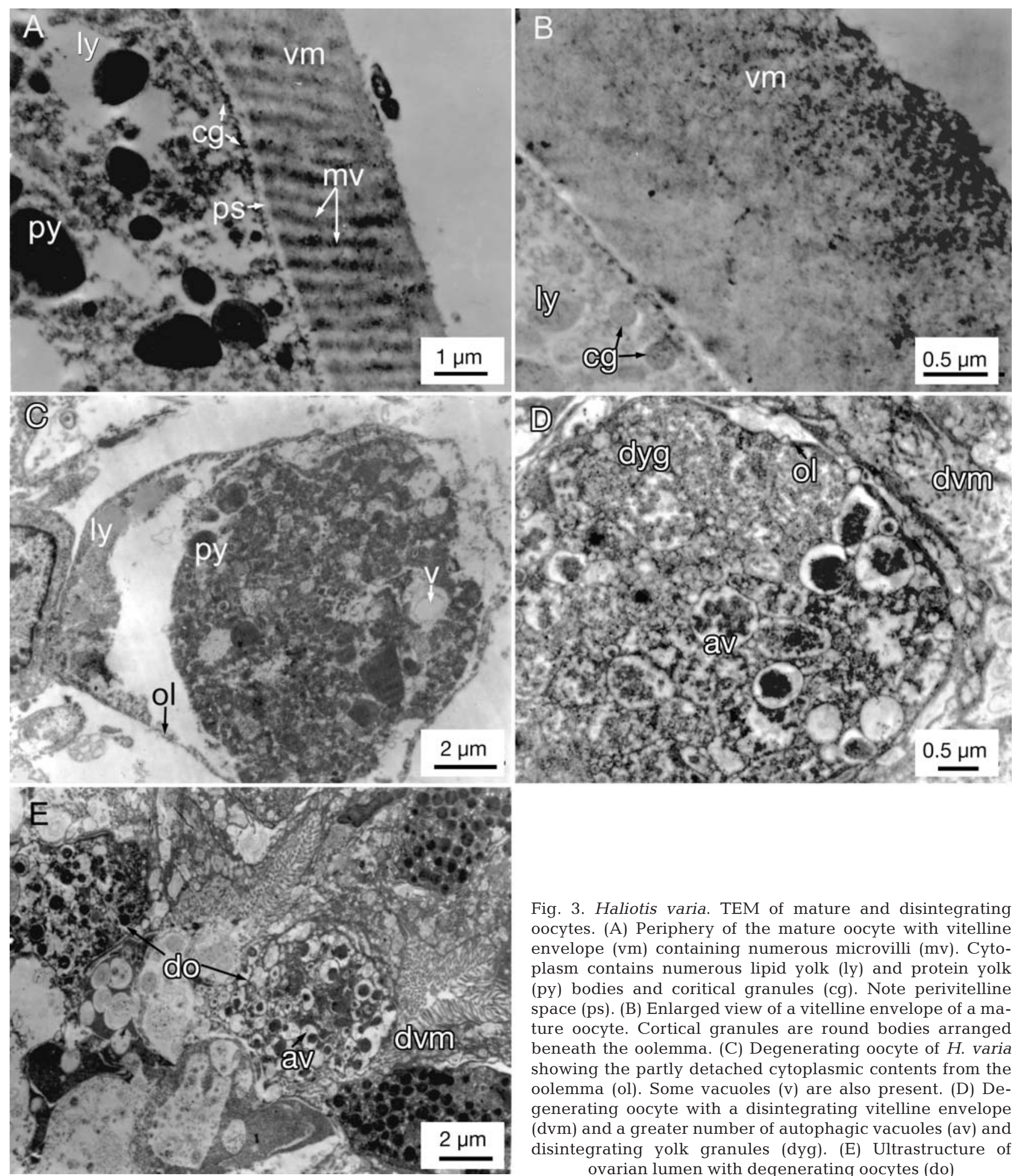

Fig. 3. Haliotis varia. TEM of mature and disintegrating oocytes. (A) Periphery of the mature oocyte with vitelline envelope (vm) containing numerous microvilli (mv). Cytoplasm contains numerous lipid yolk (ly) and protein yolk (py) bodies and coritical granules (cg). Note perivitelline space (ps). (B) Enlarged view of a vitelline envelope of a mature oocyte. Cortical granules are round bodies arranged beneath the oolemma. (C) Degenerating oocyte of $H$. varia showing the partly detached cytoplasmic contents from the oolemma (ol). Some vacuoles (v) are also present. (D) Degenerating oocyte with a disintegrating vitelline envelope $(\mathrm{dvm})$ and a greater number of autophagic vacuoles (av) and disintegrating yolk granules (dyg). (E) Ultrastructure of ovarian lumen with degenerating oocytes (do)

\section{DISCUSSION}

Oogenesis in molluscs can be divided into a generative (proliferative) and vegetative (growth) phase (Anderson 1974). During the proliferative phase, the number of oogonial cells increases in the germinal zone by

mitotic multiplication. In the vegetative phase of development, oocyte growth is very considerable, principally due to vitellogenesis, and requires substantial uptake and synthesis of nutritive materials (Pipe 1987). The oogonial cells of Haliotis varia described in the present study were similar to the description given to 
the oogonial cells of donkey's ear abalone $H$. asinina by Apisawetakan et al. (2001). The nucleus of the oogonial cells contained less condensed chromatin material scattered in the cytoplasm. Numerous ribosomes, mitochondria and lipid inclusions appeared in the cytoplasm of oogonial cells. Similarly, some irregularly shaped lipid inclusions along with ribosomes and mitochondria were reported in the oogonial cells of many other marine molluscs (Hodgson \& Eckelbarger 2000, Pal \& Hodgson 2002). The oogonial cells of $H$. varia were lined up within or in close vicinity of the germinal epithelium.

The most prominent feature of the undifferentiated oocytes of Haliotis varia was the large nucleus, which occupied more than half of the diameter of the cell. One of the first indications that an oogonium is differentiating into an oocyte is the appearance of characteristic pores in the nuclear membrane (Verhey \& Moyer 1967). Electron dense nucleolar materials were clumped together in close proximity to the nuclear pores in the primary oocytes of $H$. varia. In $H$. asinina, these materials were categorised into ribosome-linked particles around the cytoplasmic side of the nuclear membrane (Apisawetakan et al. 2001). These electron dense granular materials were clumped near the outer nuclear membrane in $H$. varia. During the early vitellogenic phase, the cytoplasm became strongly basophilic, indicating considerable synthesis of protein. RNA materials are transported from the nucleus to the cytoplasm prior to the onset of vitellogenesis. Adiyodi \& Subramoniam (1983) reported that such nuclear emissions are not uncommon in the growing oocytes of various animal groups and concluded that the transfer of nucleolar materials to the ooplasm was a prelude to protein synthesis.

Vitellogenesis is auto- and/or heterosynthetic in different molluscan species (Eckelbarger \& Young 1997, Matsumoto et al. 2003, Amor et al. 2004). In Haliotis varia, the primary oocytes entered into the vitellogenic phase at a diameter of about $50 \mu \mathrm{m}$, resulting in reduction of the basophilic nature of the ooplasm. The process of vitellogenesis in different bivalves and gastropods has been described by various workers (Pipe 1987, Eckelbarger \& Davis 1996, Pal \& Hodgson 2002, Amor et al. 2004). The present investigation using TEM provides evidence for the formation of yolk components via the autosynthetic pathway. The occurrence of pinocytotic vesicles along the plasma membrane of the oocyte has been taken as an important criterion for exogenous vitellogenesis, as it indicates the uptake of macromolecules (Jong-Brink et al. 1983). In molluscs, morphological evidence for uptake of macromolecules is presented for a number of species (Bottke \& Tiedtke 1988, Eckelbarger \& Davis 1996). The lack of micropinocytotic vesicles on the oolemma is also an indication of increased involvement of intraoocytic components in the fabrication of yolk components in $H$. varia.

Various cell organelles, such as the ER, Golgi bodies, mitochondria, autophagous vacuoles and multivesicular bodies have been assumed to be involved in the formation of yolk granules in molluscan oocytes (Eckelbarger \& Davis 1996). It is apparently the combined activity of a number of these organelles that leads to the formation of the complex proteinaceous yolk granules. Various membrane specializations comprised of rough and smooth endoplasmic reticulum were observed in the developing oocyte of Haliotis varia. The concentric membrane specializations encompassing several vesicles were seen in the developing oocyte. This may be identical to Balbiani's vitelline body, found in the oocytes of many molluscs, which plays a role in vitellogenesis (Gómez-Robles et al. 2005). Balbiani's vitelline body, which occurs in developing oocytes of a wide spectrum of species throughout the animal kingdom (Guraya 1979), was also observed in the vitellogenic oocytes of the bivalve Mytilus edulis (Pipe 1987). Similar types of membrane specializations are distributed in the vitellogenic oocytes of the neogastropod Bolinus brandaris (Amor et al. 2004). These cell organelles and membrane specializations were in close proximity to the yolk granule in the vitellogenic oocytes of $H$. varia.

In addition to the autosynthetic process, there are possibilities for heterosynthetic accumulation of yolk materials in Haliotis varia. The mechanism of transport of large molecules themselves through membranes is described in many species (Selman \& Arnold 1977, Beninger et al. 2003). They suggest that yolk precursors may be synthesized by the RER in the syncytial cytoplasm, and the passage of these yolk precursors through the syncytial plasma membrane and oolemma by this mechanism would go undetected in electron micrographs. Using molecular characterization of cDNA, Matsumoto et al. (2003) concluded that the putative vitellogenin in the Pacific oyster Crassostrea gigas is originally synthesized in the follicle cells. Another important component of the proteinaceous yolk in gastropods, ferritin, is thought to be derived from the digestive gland (Bottke \& Tiedtke 1988, Andrews et al. 1992). As in other gastropods, yolk synthesis in $H$. varia involves the direct incorporation of extraoocytic precursors from the neighboring tissues to the intra-cellularly synthesized yolk vesicles. There was a significant negative correlation between biochemical composition of the digestive gland and ovary, especially lipids and carbohydrates, in connection with the maturation process in $H$. varia, indicating the transfer of these biochemical components from the digestive gland to the ovary (Najmudeen 2007a). 
The cortical granules in Haliotis varia were arranged beneath the oolemma at the cortex of the oocyte. They were round or oval membrane-bound bodies $0.3 \mu \mathrm{m}$ in diameter. In $H$. asinina, these granules were spherical and comprised 2 types: one with a dense matrix and the other with a light matrix (Apisawetakan et al. 2001). In $H$. varia, the cortical granules were not arranged as a continuous layer along the cortex of the oocyte, in contrast to those found in many bivalve species (Pipe 1987).

Oocyte degeneration and resorption in molluscs are brought about by a variety of natural environmental conditions, such temperature extremes, desiccation, or low levels of nutrition (Dorange \& Le Pennec 1989). In Haliotis varia, during oocyte degeneration, the oocytes became globular and the vitelline envelope was lifted off the oolemma. The yolk vesicles were surrounded by autophagic vacuoles. The number of lipid droplets and lysosomes increased sharply in the ovarian trabeculae. Oocyte degeneration occurs in different stages of oocyte development in different species. In some gastropods like Viviparous viviparous, oocytes degenerate in all stages of development (Griffond 1977), while in the freshwater snail Biomphalaria glabrata only ripe oocytes, i.e. the oocytes surrounded by a follicular cavity, degenerate. However, in H. varia, oocyte degeneration was observed in early vitellogenic, late vitellogenic and mature oocytes.

Acknowledgements. I thank the director of the Central Marine Fisheries Research Institute (CMFRI), Cochin, for providing the necessary facilities. Thanks are also due to Dr. A. C. C. Victor, former Principal Scientist, CMFRI, for his guidance in conducting the work, and Mr. P. S. Sanil, Senior Scientist, CMFRI, for his help in electron microscopy. The study was financed by the Indian Council of Agricultural Research, New Delhi. The experiments comply with the current laws of India, where they were performed.

\section{LITERATURE CITED}

Adiyodi RG, Subramoniam T (1983) Arthropoda-Crustacea. In: Adiyodi KG, Adiyodi RG (eds) Reproductive biology of invertebrates, Vol 1. Oogenesis, oviposition and oosorption. Wiley, Chichester, p 443-495

Amor MJ, Ramon M, Durfort M (2004) Ultrastructural studies of oogenesis in Bolinus brandaris (Gastropoda: Muricidae). Sci Mar 68:343-353

Anderson E (1974) Comparative aspects of the ultrastructure of the female gamete. Int Rev Cytol 4:1-70

Andrews SC, Arosio P, Bottke W, Briat JF and others (1992) Structure, function, and evolution of ferritins. J Inorg Biochem 47:161-174

Apisawetakan S, Linthong V, Wanichanon C, Panasophonkul S and others (2001) Ultrastructure of female germ cells in Haliotis asinina Linnaeus. Invertebr Reprod Dev 39:67-79

Beninger PG, Le Pennec G, Le Pennec M (2003) Demonstration of nutrient pathway from the digestive system to oocytes in the gonad intestinal loop of the scallop Pecten maximus L. Biol Bull 205:83-92
Bottke W, Tiedtke A (1988) An autoradiographic and cytophotometric study of oogenesis in a pulmonate snail, Planorbarius corneus. Cell Tissue Res 252:67-77

Bussarawit S, Kawinlertwathana P, Nateevathana A (1990) Preliminary study on reproductive biology of the abalone (Haliotis varia) at Phuket, Andaman Sea coast of Thailand. Kasetsart J Nat Sci 24:529-539

Dorange G, Le Pennec M (1989) Ultrastructural study of oogenesis and oocytic degeneration in Pecten maximus from the Bay of St. Brieuc. Mar Biol 103:339-348

Dreon M, Lavarias S, Garin CF, Heras H, Pollero RJ (2002) Synthesis, distribution and levels of an egg lipoprotein from the apple snail Pomacea canaliculata (Mollusca: Gastropoda). J Exp Zool 292:323-330

Eckelbarger KJ (1994) Diversity of metazoan ovaries and vitellogenic mechanisms: implications for life history theory. Proc Biol Soc Wash 107:193-218

Eckelbarger KJ, Davis CV (1996) Ultrastructure of the gonad and gametogenesis in the eastern oyster, Crassostrea virginica. I. Ovary and oogenesis. Mar Biol 127:79-87

Eckelbarger KJ, Young CM (1997) Ultrastructure of the ovary and oogenesis in the methane-seep mollusc Bathynerita naticoidea (Gastropoda: Neritidae) from the Louisiana slope. Invertebr Biol 116:299-312

Galindo BE, Vacquier VD, Swanson WJ (2003) Positive selection in the egg receptor for abalone sperm lysin. Proc Natl Acad Sci USA 100:4639-4643

Gómez-Robles E, Rodríguez-Jaramillo C, Saucedo P (2005) Digital image analysis of lipid and protein histochemical markers for measuring oocyte development and quality in pearl oyster Pinctada mazatlanica (Hanley, 1856). J Shellfish Res 24:1197-1202

Griffond B (1977) Recherches cytologiques et experimentales sur la differentiation sexuelle et la gametogenese de la paludine Viviparus viviparus L. (mollusque gasteropode prosobranche). No. 114, These de l'Universite de Besançon

Guo X, Ford SE, Zhang F (1999) Molluscan aquaculture in China. J Shellfish Res 18:19-31

Guraya SS (1979) Recent advances in the morphology, cytochemistry and function of Balbiani's vitelline body in animal oocytes. Int Rev Cytol 59:249-321

Hahn KO (1989) Handbook of culture of abalone and other marine gastropods. CRC Press, Boca Raton, FL

Healy JM, Beames KP, Barclay DB (1998) Spermatozoa of the Australian 'greenlip' abalone Haliotis laevigata Donovan: ultrastructure and comparison with other gastropods, especially other Haliotidae (Vetigastropoda, Mollusca). Invertebr Reprod Dev 34:197-206

Hodgson AN, Eckelbarger KJ (2000) Ultrastructure of the ovary and oogenesis in six species of patellid limpets (Gastropoda: Patellogastropoda) from South Africa. Invertebr Biol 119:265-277

Hodgson AN, Ben-Ami F, Heller J (2002) Ultrastructure of oogenesis in an ovoviviparous and oviparous freshwater snail (Caenogastropoda) from Israel. Invertebr Reprod Dev 41:1-11

Jong Brink M, Boer HH, Joosse J (1983) Mollusca. In: Adiyodi KG, Adiyodi RG (eds) Reproductive biology of invertebrates, Vol 1. John Wiley, Chichester, p 297-355

Martin GG, Romero K, Miller-Walker C (1983) Fine structure of the ovary in the red abalone Haliotis rufescens (Mollusca: Gastropoda). Zoomorphology 103:89-102

Matsumoto T, Nakamura AM, Mori K, Kayano T (2003) Molecular characterisation of a cDNA encoding putative vitellogenin from the Pacific oyster Crassostrea gigas. Zool Sci $20: 37-42$ 
Najmudeen TM (2007a) Variation in biochemical composition during gonad maturation of the tropical abalone Haliotis varia Linnaeus, 1758 (Vetigastropoda: Haliotidae). Mar Biol Res 3:454-461

Najmudeen TM (2007b) Gonad maturation of the tropical abalone Haliotis varia Linnaeus 1758 (Vetigastropoda: Haliotidae). Molluscan Res 27:140-146

Najmudeen TM, Victor ACC (2004a) Seed production and juvenile rearing of the tropical abalone Haliotis varia Linnaeus, 1758. Aquaculture 234:277-292

Najmudeen TM, Victor ACC (2004b) Reproductive biology of the tropical abalone Haliotis varia from Gulf of Mannar. J Mar Biol Assoc India 46:154-161

Najmudeen TM, Ignatius B, Victor ACC, Chellam A, Kandasami D (2000) Spawning, larval rearing and production of juveniles of the tropical abalone Haliotis varia Linn. Marine Fisheries Information Service, Technical \& Extension Series 163:5-8

Osada M, Takamura T, Sato H, Mori K (2003) Vitellogenin synthesis in the ovary of scallop, Patinopecten yessoensis: control by estradiol-17, and the central nervous system. J Exp Zool 299A:172-179

Pal P (2007) Fine structure of reproductive glands in two primitive marine pulmonates (Basommatophora: Siphonariidae). Acta Zool 88:145-152

Editorial responsibility: Roderick Nigel Finn, Bergen, Norway
Pal P, Hodgson AN (2002) An ultrastructural study of oogenesis in a planktonic and a direct-developing species of Siphonaria (Gastropoda: Pulmonata). J Molluscan Stud 68: 337-344

Pipe RK (1987) Oogenesis in the marine mussel Mytilus edulis: an ultrastructural study. Mar Biol 95:405-414

Selman K, Arnold JM (1977) An ultrastructural and cytochemical analysis of oogenesis in the squid Loligo pealei. J Morphol 152:381-400

Sobhon P, Apisawetakan S, Chanpoo M, Wanichanon C and others (1999) Classification of germ cells, reproductive cycle and maturation of gonad in Haliotis asinina Linnaeus. ScienceAsia 25:3-21

Spurr AR (1969) A low viscosity epoxy resin-embedding medium for electron microscopy. J Ultrastruct Res 26:31-43

Takashima F, Okuno M, Nishimura K, Nomura M (1978) Gametogenesis and reproductive cycle in Haliotis diversicolor diversicolor Reeve. J Tokyo Univ Fish 65:1-8

Verhey CA, Moyer MH (1967) Fine structural changes during sea urchin oogenesis. J Exp Zool 164:195-207

Wilson B (1993) Australian marine shells. Prosobranch gastropods. Odyssey Publishing, Kallaroo

Young JS, DeMartini JD (1970) The reproductive cycle, gonadal histology and gametogenesis of the red abalone Haliotis rufescens (Swainson). Calif Fish Game 56:298-309

Submitted: October 10, 2007; Accepted: April 4, 2008

Proofs received from author(s): April 29, 2008 